\title{
Heparin Inhibits the Induction of Three Matrix Metalloproteinases (Stromelysin, 92-kD Gelatinase, and Collagenase) in Primate Arterial Smooth Muscle Cells
}

Richard D. Kenagy, Seppo T. Nikkari, Howard G. Welgus, and Alexander W. Clowes

Department of Surgery, University of Washington, Seattle, Washington 98195; and Division of Dermatology, Department of Medicine, Jewish Hospital at Washington University, St. Louis, Missouri 63110

\begin{abstract}
Heparin inhibits the migration and proliferation of arterial smooth muscle cells and modifies the extracellular matrix. These effects may be the result of heparin's effects on proteinases that degrade the matrix. We have previously reported that heparin inhibits the induction of tissue-type plasminogen activator and interstitial collagenase mRNA. We have investigated the possibility that heparin affects other members of the matrix metalloproteinase family. Phorbol ester increased the levels of mRNA of collagenase, 92-kD gelatinase and stromelysin as well as the synthesis of these proteins. These effects were inhibited by heparin, but not by other glycosaminoglycans, in a dosedependent manner. The induction of these matrix metalloproteinases was also inhibited by staurosporine and pretreatment with phorbol ester indicating the involvement of the protein kinase $\mathrm{C}$ pathway. In contrast, the 72-kD gelatinase was expressed constitutively and was not affected by phorbol ester or heparin. Tissue inhibitor of metalloproteinases-1 was expressed constitutively and was slightly increased by phorbol ester. It was not affected by heparin. Thus, heparin inhibits the production of four proteinases (tissue plasminogen activator, collagenase, stromelysin and 92-kD gelatinase) that form an interdependent system capable of degrading all the major components of the extracellular matrix. (J. Clin. Invest. 1994. 93:1987-1993.) Key words: arteriosclerosis • extracellular matrix $\cdot$ gene expression regulation $\cdot$ glycosaminoglycans $\bullet$ protein kinase $\mathbf{C}$
\end{abstract}

\section{Introduction}

Heparin inhibits the proliferation and migration of arterial smooth muscle cells (SMC) ${ }^{1}$ in vivo and in vitro (1-4) and alters the amount and type of extracellular matrix $(5,6)$. These

Portions of this work were presented at the 31 st Annual Meeting of the American Society for Cell Biology, Boston, MA, 1992.

Address all correspondence to Dr. R. D. Kenagy, Department of Surgery RF-25, University of Washington School of Medicine, Seattle, WA 98195.

Received for publication 21 September 1993 and in revised form 10 December 1993.

1. Abbreviations used in this paper: APMA, $p$-aminophenyl-mercuric acetate; GAPDH, glyceraldehyde 3-phosphate dehydrogenase; PMA, phorbol myristate acetate; SMC, smooth muscle cells; TIMP-1, tissue inhibitor of metalloproteinases-1; TRE, phorbol ester response element.

J. Clin. Invest.

(c) The American Society for Clinical Investigation, Inc. 0021-9738/94/05/1987/07 \$2.00

Volume 93, May 1994, 1987-1993 effects may in part be accounted for by altered growth factor binding (7) or inhibition of growth factor receptor (8) or transcription factor $(9,10)$ expression. Other possible mechanisms include the release of the inhibitory factor transforming growth factor $\beta$ (TGF $\beta$ ) from binding proteins (11) and the release and removal from the cell layer of fibroblast growth factor and the progression factor thrombospondin (12-14).

We have been investigating the hypothesis that heparin interferes with the expression or action of extracellular proteinases. We have previously reported that heparin prevents the increased expression of tissue-type plasminogen activator (tPA; 15) and interstitial collagenase (16) mRNA caused by treatment of arterial SMC with phorbol esters or serum. Heparin also inhibits tPA expression induced in vivo in SMC by arterial injury (17). These effects of heparin are specific for this glycosaminoglycan, and expression of other genes such as urokinase and platelet-derived growth factor $A$ and $B$ chains is not affected by heparin.

In this study, we explored the possibility that heparin regulates other members of the matrix metalloproteinase family and determined that stromelysin (MMP3) and the 92-kD gelatinase (MMP9) are inhibited, while the $72-\mathrm{kD}$ gelatinase (MMP2) is not. In addition, tissue inhibitor of metalloproteinases-1 (TIMP-1) is not affected by heparin.

\section{Methods}

Materials. Cell culture medium and additives were purchased from Sigma Chemical Co. (St. Louis, MO) unless indicated otherwise. Electrophoresis supplies were obtained from Bio Rad Laboratories (Richmond, CA) and National Diagnostics, Inc. (Mannville, NJ). Fetal bovine serum was purchased from either GIBCO BRL (Gaithersburg, MD) or Hyclone Laboratories (Logan, UT). Phorbol myristate acetate (PMA) and heparin (porcine type II) were from Sigma Chemical Co. Dermatan sulfate, chondroitin 6-sulfate and chondroitin 4-sulfate were from ICN (Costa Mesa, CA). Antisera to 92-kD gelatinase (18), stromelysin (19), collagenase (20), and tissue inhibitor of metalloproteinases-1 (21) were prepared and characterized as described previously. A monoclonal antibody to $72-\mathrm{kD}$ gelatinase raised against a polypeptide of the proenzyme region was obtained from Molecular Oncology, Inc. (Gaithersburg, MD).

Cell culture. Explants were made from the media of thoracic aortas of male baboons (Papio cynocephalus) about three years old and SMC allowed to grow out in Dulbecco-Vogt medium with $10 \%$ fetal bovine serum (22). After passage the cells were routinely maintained in 5\% calf serum and Mito+(Collaborative Research, Inc., Bedford, MA). Cell lines were used between passages 4 and 13. For experiments, cells were seeded at $20,000 / \mathrm{cm}^{2}$ in Dulbecco's Modified Eagle's/Ham's F12 (1:1) with $6 \mu \mathrm{g}$ insulin $/ \mathrm{ml}, 5 \mu \mathrm{g}$ transferrin $/ \mathrm{ml}$, and $1 \mathrm{mg}$ ovalbu$\mathrm{min} / \mathrm{ml}$ essentially as described (23) onto dishes precoated with $2 \%$ calf serum $\left(1 \mathrm{~h}\right.$ at $37^{\circ} \mathrm{C}$ followed by a wash ). After $3 \mathrm{~d}$ in this growtharrest medium, the medium was changed to fresh serum-free medium with insulin and transferrin and additions as indicated. For PMA pretreatment experiments, $100 \mathrm{ng}$ PMA/ml was added to the SMC $24 \mathrm{~h}$ before the end of the 3-d growth-arrest period. To terminate an experi- 
ment the medium was removed, centrifuged at $1,500 \mathrm{rpm}$ for $10 \mathrm{~min}$ and aliquots of supernatant were frozen at $-70^{\circ} \mathrm{C}$. The cell layer was washed once with phosphate buffered saline and the cells were scraped into extraction buffer $(0.1 \mathrm{M}$ Tris, $0.2 \%$ Triton X-100, $200 \mathrm{U}$ aprotinin $/ \mathrm{ml}, 10 \mathrm{mM}$ EDTA, $5 \mathrm{mM}$ iodoacetamide, $\mathrm{pH} \mathrm{8.1)}$. Aliquots were frozen at $-70^{\circ} \mathrm{C}$. Protein was measured (Bio Rad Laboratories) with bovine serum albumin as a standard.

Electrophoresis/Western blotting/zymography. Electrophoresis was performed as described by Laemmli (24) using $10 \%$ polyacrylamide gels. For zymography either casein or gelatin was incorporated into the gels at $1 \mathrm{mg} / \mathrm{ml}$. The gels were washed for $30 \mathrm{~min}$ with $2.5 \%$ Triton X-100, incubated in $50 \mathrm{mM}$ Tris, $10 \mathrm{mM} \mathrm{CaCl}_{2}, \mathrm{pH} 7.8$ at $37^{\circ} \mathrm{C}$ for $18 \mathrm{~h}$ and stained with Coomassie blue $\mathrm{R}(25)$. Western transfers to nitrocellulose were performed at $70 \mathrm{~V}$ for $3 \mathrm{~h}$ in $20 \%$ methanol, $25 \mathrm{mM}$ Tris, and $192 \mathrm{mM}$ Glycine at room temperature. Blots were incubated with appropriate antisera to collagenase, stromelysin, TIMP-1 (each at $1: 2,500)$, or $92-\mathrm{kD}$ gelatinase $(1: 500)$. A monoclonal antibody was used against $72-\mathrm{kD}$ gelatinase $(1 \mu \mathrm{g} / \mathrm{ml})$. To detect $92-\mathrm{kD}$ gelatinase the medium was concentrated 10 -fold by a combination of using Aquacide I on the medium in dialysis bags (Calbiochem-Novabiochem Corp., LaJolla, CA) followed by centrifugal concentration (Centricon 10; Amicon Corp., Beverly, MA).

Northern analysis. Total RNA was isolated (26) and transferred to nylon membranes (15) for analysis as described previously. Specific cDNA probes for collagenase $(2.05 \mathrm{~kb} ; 27), 92$ gelatinase $(0.56 \mathrm{~kb}$; 28 ), stromelysin ( $1.5 \mathrm{~kb} ; 29), 72$ gelatinase ( $2.18 \mathrm{~kb} ; 30)$, TIMP-1 ( 0.7 $\mathrm{kb}$; 31 ), and glyceraldehyde 3-phosphate dehydrogenase (GAPDH; 32) were labeled by nick translation with ${ }^{32} \mathrm{P}$. Blots were quantitated using PhosphorImager analysis (Molecular Dynamics, Inc., Sunnyvale, CA) with standardization against GAPDH.

Radioimmunoprecipitation. For metabolic labeling experiments medium on growth arrested SMC was changed to the same medium with insulin and transferrin but lacking methionine. $\left[{ }^{35} \mathrm{~S}\right]$ methionine ( $50 \mu \mathrm{Ci} / \mathrm{ml}$; Amersham, Arlington Heights, IL) was added with other factors as indicated such as $10 \%$ dialyzed fetal bovine serum (dialyzed $24 \mathrm{~h}$ against 500 vol of $0.05 \mathrm{M}$ Tris, $0.15 \mathrm{M} \mathrm{NaCl}, \mathrm{pH} 7.5$ to remove unlabeled methionine).

Collagenase ELISA. ELISA for interstitial collagenase was performed on 16-h conditioned medium as described previously (33). This assay recognizes both free collagenase and collagenase bound to tissue inhibitor of metalloproteinases (TIMP).

Statistical analysis. $t$-tests were performed using SPSS/PC+ (SPSS, Inc., Chicago, IL). All values are the mean \pm SEM of the indicated number of experiments.

\section{Results}

Western and zymographic analysis of the effect of heparin on the production of matrix metalloproteinases. To determine whether heparin regulates the production of matrix metalloproteinases, we performed Western and zymographic analysis. Collagenase, stromelysin, and $92-\mathrm{kD}$ gelatinase were undetectable in the medium of control cells. Treatment with PMA dramatically increased these enzymes as documented by gelatin zymography for collagenase and 92-kD gelatinase (Fig. $1 A$ ) and by casein zymography for stromelysin (Fig. $1 B$ ). Positive identification of collagenase and $92-\mathrm{kD}$ gelatinase or of stromelysin by gelatin or casein zymography, respectively, was made by specific immunoprecipitation of each enzyme by their respective antisera. In addition, all gelatinase and caseinase activities were inhibited by $10 \mathrm{mM}$ EDTA (data not shown). The apparent molecular weights of collagenase, $92-\mathrm{kD}$ gelatinase, and stromelysin suggest that each enzyme is in the inactive proform. Treatment with $1 \mathrm{mM} p$-aminophenylmercuric acetate (APMA) converted the $96-\mathrm{kD}$ zymogen to the $85-\mathrm{kD}$ active form (Fig. 2).
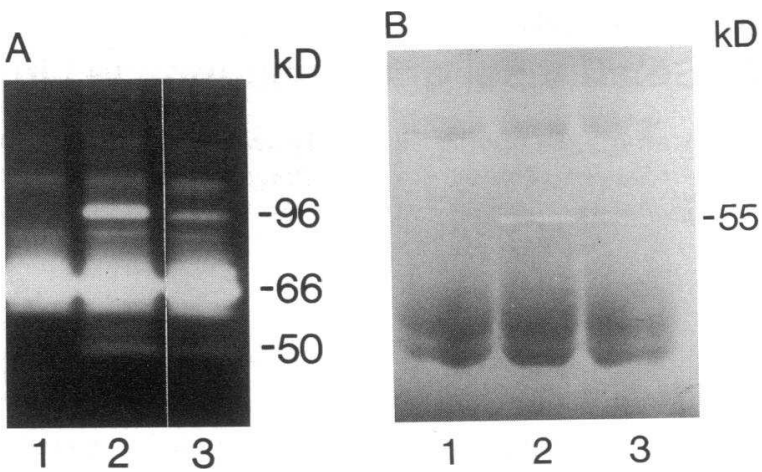

Figure 1. Effect of PMA and heparin on production of metalloproteinases. Growth-arrested SMC were treated with control medium (lane 1), $5 \mathrm{ng}$ PMA $/ \mathrm{ml}$ (lane 2), or with $5 \mathrm{ng}$ PMA $/ \mathrm{ml}+50 \mu \mathrm{g} / \mathrm{ml}$ heparin (lane 3 ). After $16 \mathrm{~h}$ medium was collected and subjected to electrophoresis in gelatin $(A)$ or casein $(B)$ containing gels. After incubation at $37^{\circ} \mathrm{C}$ for $18 \mathrm{~h}$ the gels were stained. Note the induction by PMA and inhibition by heparin of $92-\mathrm{kD}$ gelatinase $(96 \mathrm{kD})$ and collagenase $(50 \mathrm{kD})$ in $\mathrm{A}$ and of stromelysin $(55 \mathrm{kD})$ in $B$. These results are representative of 7-16 experiments.

Simultaneous treatment of SMC with heparin inhibited the PMA-mediated induction of collagenase, stromelysin, and 92$\mathrm{kD}$ gelatinase production (Fig. 1). In addition, the measurement of collagenase protein in conditioned medium by ELISA for SMC treated for $16 \mathrm{~h}$ with PMA or PMA and heparin gave values of $641 \pm 92$ and $137 \pm 42 \mathrm{ng} / \mathrm{mg}$ cellular protein, respectively, (mean \pm SEM of three experiments, $P<0.01$ PMA vs PMA+heparin ) compared to control values of $137 \pm 10$. These results for collagenase were confirmed by Western analysis. 92-kD gelatinase and stromelysin protein were also decreased by heparin (Fig. 3). Control experiments showed that addition of $100 \mu \mathrm{g}$ heparin/ml to medium from PMA-treated SMC before electrophoresis had no effect on the activity or protein detected by zymography or Western blotting.

In contrast with the other metalloproteinases the $72-\mathrm{kD}$ gelatinase was expressed constitutively in the conditioned medium and was not reproducibly affected by PMA or heparin (Fig. 1 $A$ ). Heparin treatment of control cells had no effect on the constitutive expression of $72-\mathrm{kD}$ gelatinase, nor did it induce the expression of collagenase, stromelysin and $92-\mathrm{kD}$ gela-

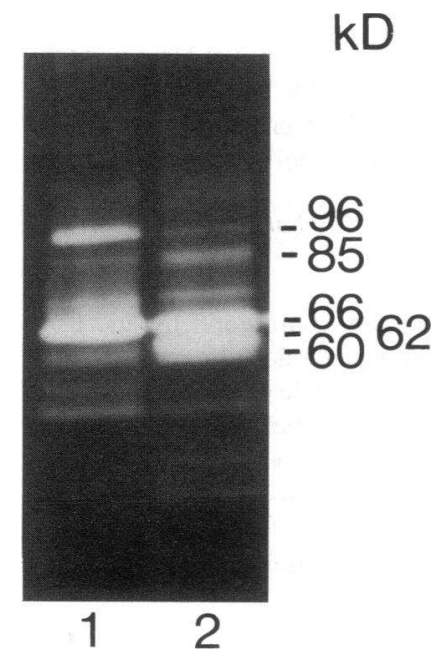

Figure 2. Effect of APMA on processing of metalloproteinases. Conditioned medium from PMA ( $5 \mathrm{ng} / \mathrm{ml}$ ) treated SMC was collected after $16 \mathrm{~h}$ and incubated with (lane 2) or without (lane 1) $1 \mathrm{mM}$ APMA at $37^{\circ} \mathrm{C}$ for $1 \mathrm{~h}$. Samples were then analyzed by gelatin zymography. 


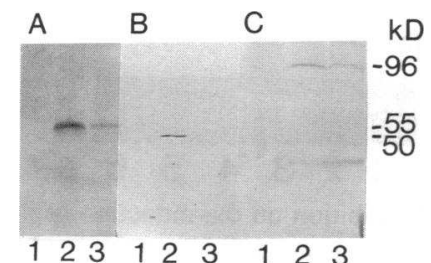

Figure 3. Effects of PMA and heparin on $92-\mathrm{kD}$ gelatinase, stromelysin, and collagenase protein analyzed by Western. Medium from SMC treated for $16 \mathrm{~h}$ with control medium (lane 1), $5 \mathrm{ng}$ PMA/ml (lane 2 ), or with $5 \mathrm{ng} P M A / \mathrm{ml}+50$ $\mu \mathrm{g}$ heparin/ml (lane 3) was

subjected to electrophoresis, transferred to nitrocellulose membranes, and stained by antiserum to stromelysin $(A)$, collagenase $(B)$, or $92-$ $\mathrm{kD}$ gelatinase $(C)$. These results are representative of 2-8 experiments.

tinase (data not presented). By zymography major and minor bands of activity were present at 66 and $60 \mathrm{kD}$, respectively (non-reducing conditions). After APMA activation of medium from either control (not shown) or PMA-treated SMC (Fig. 2) a 62-kD form appeared, as observed with human fibroblasts (34). The antibody against a peptide of the pro-region of the 72-kD gelatinase stained only the $66-\mathrm{kD}$ form (Fig. 4 ) and specifically immunoprecipitated the $66-\mathrm{kD}$ form observed by gelatin zymography (data not presented). This suggests the 66$\mathrm{kD}$ form represents the same pro-72-kD gelatinase seen in human fibroblasts $(34,35)$. The $60-\mathrm{kD}$ form probably represents endogenously activated gelatinase as suggested by Overall et al. (34) and Brown et al. (36). The 72-kD gelatinase was also found in the cell layer, while collagenase, stromelysin, and the 92-kD gelatinase were not (data not shown).

Heparin inhibits the synthesis of collagenase, 92-kD gelatinase, and stromelysin. To determine whether heparin inhibits the biosynthesis of collagenase, stromelysin and $92-\mathrm{kD}$ gelatinase, we metabolically labeled SMC with $\left[{ }^{35} \mathrm{~S}\right]$ methionine. The products were immunoprecipitated with specific antisera for the enzymes and analyzed by gel electrophoresis. Collagenase, 92-kD gelatinase, and stromelysin synthesis could not be detected in growth-arrested SMC; these observations confirm the results from Western and zymographic analysis. Serum and, to a much greater extent, PMA increased synthesis of stromelysin (Fig. $5 A$ ) and collagenase (Fig. $5 B$ ), the latter showing a characteristic doublet of glycosylated and nonglycosylated forms previously observed (20). Detection of the $92-\mathrm{kD}$ gelatinase required concentrating the medium of PMA treated SMC (Fig. $5 C$ ). Concomitant treatment with heparin largely prevented the PMA-induced biosynthesis of all three metalloproteinases (Fig. 5, $A-C$ ). Cell layers did not contain detectable levels of any of these enzymes (data not presented). Total TCA precipitable ${ }^{35} \mathrm{~S}$-labeled protein in the medium was not de-

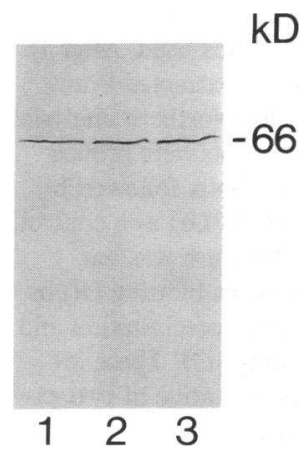

Figure 4. Effects of PMA and heparin on 72-kD gelatinase protein. Medium from SMC treated for $16 \mathrm{~h}$ with either control medium (lane 1), $5 \mathrm{ng}$ PMA/ml (lane 2 ), or with $5 \mathrm{ng} P M A / \mathrm{ml}+50 \mu \mathrm{g}$ hepa$\mathrm{rin} / \mathrm{ml}$ (lane 3 ) was analyzed by Western blotting. Membranes were stained with a monoclonal antibody to a peptide of the pro-region of the $72-\mathrm{kD}$ gelatinase. This result is representative of three experiments.

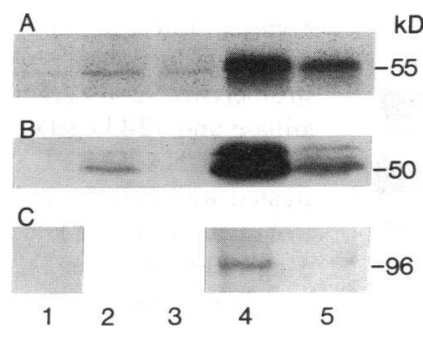

Figure 5. Effects of PMA, FBS, and heparin on biosynthesis of stromelysin, collagenase and 92-kD gelatinase. Growtharrested SMC were treated with either control medium lacking methionine (lane 1), 10\% FBS (lane 2), 10\% FBS $+50 \mu \mathrm{g}$ heparin/ml (lane 3), $5 \mathrm{ng}$ $\mathrm{PMA} / \mathrm{ml}$ (lane 4), or $5 \mathrm{ng}$ $\mathrm{PMA} / \mathrm{ml}+50 \mu \mathrm{g}$ heparin $/ \mathrm{ml}$

(lane 5) in the presence of $50 \mu \mathrm{Ci}\left[{ }^{35} \mathrm{~S}\right]$ methionine $/ \mathrm{ml}$. After $16 \mathrm{~h}$ medium was immunoprecipitated using antisera to stromelysin $(A)$, collagenase $(B)$, or $92-\mathrm{kD}$ gelatinase $(C)$. These results are representative of at least two experiments.

creased by heparin $(113 \pm 2 \%$ and $96 \pm 14 \%$ of serum and PMA alone, respectively; mean \pm SEM of $3-5$ experiments; $P$ $>0.05$ ).

Since in these experiments SMC were metabolically labeled for $16 \mathrm{~h}$, the decrease in proteinase expression could have been due to decreased synthesis, increased degradation, or both. To determine if significant degradation of enzymes occurred during this time, medium of $\left[{ }^{35} \mathrm{~S}\right]$ methionine labeled, PMAtreated SMC was removed after $16 \mathrm{~h}$ and another $5 \mathrm{ng}$ PMA/ $\mathrm{ml}$ was added. The conditioned medium was then added to fresh SMC with or without added heparin. There was no consistent loss of collagenase or stromelysin from the medium for up to $24 \mathrm{~h}$ whether or not heparin was present (data not presented). These findings support the conclusion that heparin inhibited the synthesis but not the degradation of these proteins. In addition, the lack of a change in molecular weight of the proteinases indicates there was no activation of the proenzymes under these conditions.

Stimulation of stromelysin and 92-kD gelatinase $m R N A$ by PMA and inhibition by heparin. Having shown that PMA increases collagenase, $92-\mathrm{kD}$ gelatinase, and stromelysin biosynthesis, we next investigated whether these effects were the result of increased mRNA as has been observed for collagenase (16). As shown in Fig. 6, 92-kD gelatinase and stromelysin mRNA was increased from undetectable levels by PMA. Treatment with heparin inhibited the induction by PMA of stromelysin (by 84 and $78 \% ; n=2$ ) and $92-\mathrm{kD}$ gelatinase mRNA (by 62 and $71 \% ; n=2$ ).

Effects of heparin: specificity and dose-response. As previously observed for collagenase and tPA $(15,16)$ the inhibition of stromelysin and 92-kD gelatinase (Fig. 7) was specific for heparin and was not seen with chondroitin sulfate. The effect of heparin was also dose dependent and was maximal at 50$100 \mu \mathrm{g} / \mathrm{ml}$ (data not presented).

The effects of serum and PMA on stromelysin and 92-kD gelatinase production are mediated in part by protein kinase $C$. The induction of collagenase by serum and PMA in SMC is mediated at least in part by protein kinase $\mathrm{C}(16)$ as in other cell types (18). Therefore, we investigated the effects of staurosporine and pretreatment with PMA to determine whether protein kinase $\mathrm{C}$ was involved in the stimulation of stromelysin and $92-\mathrm{kD}$ gelatinase. Levels of the $92-\mathrm{kD}$ gelatinase and stromelysin were decreased by staurosporine and by pretreatment of cells with $100 \mathrm{ng} / \mathrm{ml}$ PMA for $24 \mathrm{~h}$, which is consistent with a role for protein kinase C (Fig. 8). 


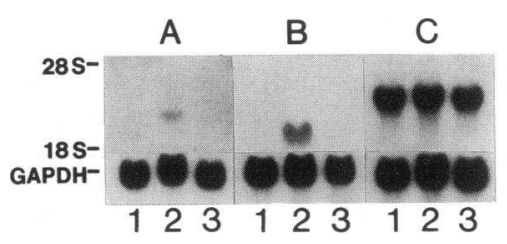

Figure 6. Effect of heparin on induction of stromelysin, 92-kD gelatinase and $72-\mathrm{kD}$ gelatinase mRNA. SMC treated with either control medium (lane 1 ), 5 ng PMA/ml (lane 2), or with $5 \mathrm{ng} \mathrm{PMA} / \mathrm{ml}+100 \mu \mathrm{g}$ heparin $/ \mathrm{ml}$ (lane 3) were harvested at $16 \mathrm{~h}$ for total RNA extraction. $20 \mu \mathrm{g}$ RNA per lane was loaded and blots were hybridized for 92-kD gelatinase $(A ; 2.8 \mathrm{~kb})$, stromelysin $(B ; 1.9 \mathrm{~kb})$, or $72-\mathrm{kD}$ gelatinase $(C ; 3.4 \mathrm{~kb})$. Levels of GAPDH are shown as controls for loading. These results are representative of two experiments.

The effects of PMA and heparin on TIMP-1 protein and synthesis. Having demonstrated that heparin inhibits the production of several metalloproteinases, we investigated the effects of heparin on a major inhibitor of these proteinasesTIMP-1. TIMP-1 mRNA $(0.9 \mathrm{~kb})$ and protein $(24,26 \mathrm{kD})$ was expressed constitutively by the growth-arrested cells (Fig. 9, $A-C$, lane 1 ). PMA increased TIMP-1 mRNA, protein, and synthesis about twofold (Fig. 9, $A-C$ ), and addition of heparin had no effect.

\section{Discussion}

We have shown that baboon arterial SMC, like other arterial SMC (37-41), express the matrix metalloproteinases collagenase, stromelysin, and the 72- and $92-\mathrm{kD}$ gelatinases, as well as the inhibitor TIMP-1. SMC also express the plasminogen activators, urokinase and tPA $(15,42,43)$. The substrates for these enzymes comprise the major components of the extracellular matrix of SMC, including collagens I through V, elastin, proteoglycans, and various glycoproteins. SMC have been shown to degrade the extracellular matrix by plasmin-dependent and -independent mechanisms (44). There is an intricate relationship between these enzymes with regard to the regulation of activity. For example, plasmin activates collagenase, $92-\mathrm{kD}$ gelatinase, and stromelysin (45-47) and stromelysin activates collagenase $(48,49)$ and $92-\mathrm{kD}$ gelatinase $(50)$. Urokinase may also activate $72-\mathrm{kD}$ gelatinase $(51,52)$. In addition, collagenase is able to degrade various serpins (53) and several serine proteinases can degrade TIMP-1 (54) illustrating possible regulation of the inhibitory side of proteinase systems.

It is of great significance that heparin has inhibitory effects on the production of four of these six enzymes, namely collage-
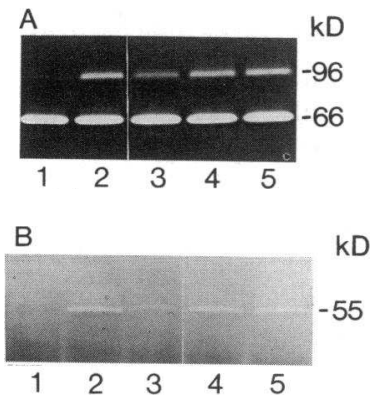

Figure 7. Specificity of heparin's inhibition of stromelysin and 92$\mathrm{kD}$ gelatinase production. Growth arrested SMC were treated with control medium alone (lane 1 ), 5 ng PMA/ml (lane 2), PMA and $100 \mu \mathrm{g} / \mathrm{ml}$ heparin (lane 3), PMA and $100 \mu \mathrm{g} / \mathrm{ml}$ chondroitin-4-sulfate (lane 4), or PMA and 100 $\mu \mathrm{g} / \mathrm{ml}$ chondroitin-6-sulfate (lane $5)$. After $16 \mathrm{~h}$ medium was harvested for gelatin $(A)$ or casein $(B)$ zymography. A second experiment gave the same results.
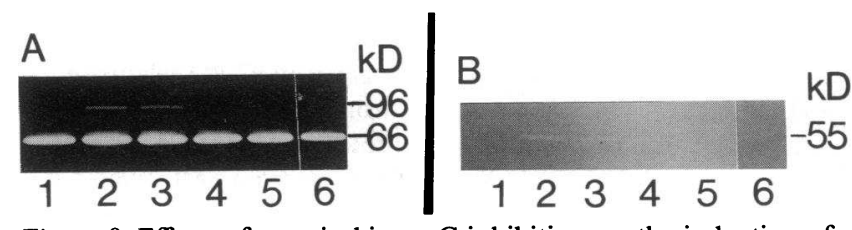

Figure 8. Effects of protein kinase $\mathrm{C}$ inhibition on the induction of stromelysin and $92-\mathrm{kD}$ gelatinase. Growth arrested SMC were treated with either control medium (lane 1), $5 \mathrm{ng} \mathrm{PMA} / \mathrm{ml}$ (lanes 2 and 5), $5 \mathrm{ng}$ PMA $/ \mathrm{ml}+14 \mathrm{nM}$ staurosporine (lane 3), $5 \mathrm{ng} \mathrm{PMA} / \mathrm{ml}+35$ $\mathrm{nM}$ staurosporine (lane 4) or $5 \mathrm{ng} \mathrm{PMA} / \mathrm{ml}+100 \mu \mathrm{g}$ heparin $/ \mathrm{ml}$ (lane 6). Some SMC were pretreated for $24 \mathrm{~h}$ with $100 \mathrm{ng}$ PMA $/ \mathrm{ml}$ (lane 5). Medium was harvested at $16 \mathrm{~h}$ and analyzed by gelatin $(A)$ or casein $(B)$ zymography. A second experiment gave the same results.

nase, stromelysin, 92-kD gelatinase, and tPA. Heparin also inhibits the production of a molecule immunologically similar to major excreted protein (MEP)/cathepsin L (55), which is a thiol proteinase able to degrade collagen at acid $\mathrm{pH}$. The inhibitory effects of heparin on the synthesis and secretion of these enzymes might explain why extracellular matrix accumulates to a greater extent in the intima of injured carotid arteries of rats treated with heparin compared with control (6). Heparin may also have direct effects on these enzymes. It can displace bound urokinase (56). Heparin may alter the activity of the metalloproteinases (57) as it does the plasminogen activators (58). Finally, heparin probably does not function by increasing the concentration of proteinase inhibitors since heparin does not alter production of TIMP-1 or plasminogen activator inhibitor-1 in baboon SMC (15).

The requirement of proteinases for the migration of cells through extracellular matrices has been demonstrated for various tumor cells (59), monocytes (60), embryonic cells (61), and endothelial cells (62). A role for matrix metalloproteinases in proliferation is less clear, although stromelysin has also been shown to play a role in dermal papilla cell proliferation in vitro (63). Inhibition of metalloproteinases with synthetic inhibitors inhibits SMC proliferation and SMC migration from medial explants of rabbit aorta in vitro (38). We have also found matrix metalloproteinase inhibitors inhibit SMC migration from primate aortic explants (64). In these

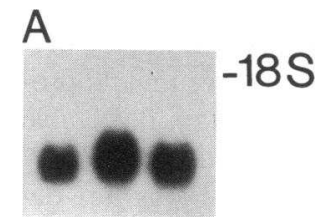

-0 GAPDH
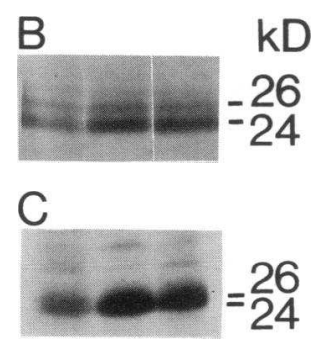

123
Figure 9. Effects of PMA and heparin on TIMP-1. Growth-arrested SMC were treated with control medium (lane 1), $5 \mathrm{ng}$ PMA $/ \mathrm{ml}$ (lane 2), or with $5 \mathrm{ng}$ PMA/ml $+100 \mu \mathrm{g}$ heparin $/ \mathrm{ml}$ (lane 3 ). To measure TIMP synthesis basal medium without methionine and containing $50 \mu \mathrm{Ci}\left[{ }^{35} \mathrm{~S}\right]-$ methionine $/ \mathrm{ml}$ was used. After 16 $h$ total RNA was extracted from the cell layer for Northern analysis $(A)$. Northern blots were probed with TIMP-1 cDNA followed by probing with GAPDH as a control for loading. Medium was harvested for Western blotting $(B)$ or for radioimmunoprecipitation and autoradiography $(C)$. These results are representative of two experiments each. 
explant systems where metalloproteinases play a role in migration, heparin increases the lag time before SMC migrate from the tissue $(64,65)$, consistent with the hypothesis that heparin decreases SMC migration by inhibiting these enzymes. Treatment of aortic explants with elastase (65) or bacterial collagenase/elastase (R. D. Kenagy and A. W. Clowes, unpublished data) decreases the lag time before SMC migrate from explants further suggesting a role for matrix degrading enzymes in migration.

Heparin inhibits collagenase and tPA production at the transcriptional level $(15,16)$. Heparin appears to act on these proteinases via the protein kinase $C$ pathway and the AP-1 family of transcription factors. Whether the changes in mRNA of stromelysin and 92-kD gelatinase reflect transcriptional regulation remains to be determined. Heparin may also regulate SMC proliferation and other genes by interfering with this pathway $(9,66-68)$ at a point distal to protein kinase $C$ itself $(9,67)$, though this is not certain (69). Angel et al. (27) have described a phorbol ester response element (TRE) which can mediate PMA induction of collagenase. The TRE binds the trans-acting factor AP-1, which is a dimer of members of the fos and jun families of transcription factors (70). Stromelysin (71), 92-kD gelatinase (72), and tPA (73) also have TRE or TRE-like sequences in their 5' regulatory regions and the effects of PMA and serum on collagenase (16), tPA (15), stromelysin, and 92-kD gelatinase (see Fig. 9) are inhibited by protein kinase $\mathrm{C}$ inhibitors such as staurosporine and chronic treatment with high levels of PMA. The lack of a TRE site in the 5 ' region of $72-\mathrm{kD}$ gelatinase $(74)$ is consistent with the lack of induction of this gene by PMA and confirms results with human fibroblasts (18). Heparin has been shown to inhibit transcription from a multiple TRE construct in transient transfection studies (16). However, the regulation of collagenase and tPA also involves complex cooperation between the TRE and other sites such as AP-2 and PEA-3 $(73,75,76)$. Thus, it is not surprising that heparin does not indiscriminately inhibit genes containing a TRE. For example, TIMP-1 has a TRE-like element (77) and is not affected by heparin. In addition, other regulatory sites may be involved. For example, collagenase (78), 92-kD gelatinase (72), stromelysin (78), and tPA (79) have TGF $\beta$ inhibitory elements in their $5^{\prime}$ regulatory regions, while the $72-\mathrm{kD}$ gelatinase does not $(80)$. Because heparin can inhibit SMC proliferation by releasing TGF $\beta$ from inhibitory binding proteins ( 11 ) and latent TGF $\beta$ is activated by plasmin (81), TGF $\beta$ may play a role in the inhibition of these proteinases by heparin. More recently, stimulation of the AP-1 factor JUN-B by PMA has also been found to be inhibited by heparin (82).

Whether heparin is acting outside or inside the cell has not been determined. SMC bind and internalize heparin (83). Also, it is of interest to note that endothelial and SMC heparan sulfate possess inhibitory activity for SMC growth $(84,85)$. This observation raises the possibility that heparin-like molecules may play a role in pathophysiological growth control perhaps through uptake and nuclear translocation of the molecule. This possibility is further reinforced by studies of a nuclear heparan sulfate demonstrating an inverse correlation of concentration with hepatocyte proliferation (86).

In summary, heparin suppresses the stimulation of four different extracellular matrix degrading proteinases-interstitial collagenase, stromelysin, 92-kD gelatinase, and tPAwhile having no effect on TIMP-1. This is of significance for matrix metabolism and probably for migration of SMC through matrix. Exploring the similarities in the 5 ' regulatory regions of these genes compared with differences from other PMA inducible, heparin insensitive genes may lead to a better understanding of the molecular mechanism of heparin's actions.

\section{Acknowledgments}

We thank Kitty Ratcliff for technical assistance.

This work was supported by National Institutes of Health grants HL18645, HL30946, HL29594, and RR00166.

\section{References}

1. Clowes, A. W., and M. J. Karnovsky. 1977. Suppression by heparin of smooth muscle cell proliferation in injured arteries. Nature (Lond.). 265:625626.

2. Hoover, R. L., R. Rosenberg, W. Haering, and M. J. Karnovsky. 1980. Inhibition of rat arterial smooth muscle cell proliferation by heparin. II. In vitro studies. Circ. Res. 47:578-583.

3. Clowes, A. W., and M. M. Clowes. 1986. Kinetics of cellular proliferation after arterial injury. IV. Heparin inhibits rat smooth muscle mitogenesis and migration. Circ. Res. 58:839-845.

4. Majack, R. A., and A. W. Clowes. 1984. Inhibition of vascular smooth muscle cell migration by heparin-like glycosaminoglycans. J. Cell. Physiol. 118:253-256.

5. Snow, A. D., R. P. Bolender, T. N. Wight, and A. W. Clowes. 1990. Heparin modulates the composition of the extracellular matrix domain surrounding arterial smooth muscle cells. Am. J. Pathol. 137:313-330.

6. Clowes, A. W., and M. M. Clowes. 1985. Kinetics of cellular proliferation after arterial injury. II. Inhibition of smooth muscle growth by heparin. Lab. Invest. 52:611-616.

7. Fager, G., G. Camejo, and G. Bondjers. 1992. Heparin-like glycosaminoglycans influence growth and phenotype of human arterial smooth muscle cells in vitro. I. Evidence for reversible binding and inactivation of the platelet-derived growth factor by heparin. In Vitro Cell. \& Dev. Biol. 28A:168-175.

8. Reilly, C. F., L. M. S. Fritze, and R. D. Rosenberg. 1988. Heparin-like molecules regulate the number of epidermal growth factor receptors on vascular smooth muscle cells. J. Cell. Physiol. 136:23-32.

9. Pukac, L. A., J. J. Castellot, Jr., T. C. Wright, Jr., B. L. Caleb, and M. J. Karnovsky. 1990. Heparin inhibits c-fos and c-myc mRNA expression in vascular smooth muscle cells. Cell Regul. 1:435-443.

10. Reilly, C. F., M. S. Kindy, K. E. Brown, R. D. Rosenberg, and G. E. Sonenshein. 1989. Heparin prevents vascular smooth muscle cell progression through the G1 phase of the cell cycle. J. Biol. Chem. 264:6990-6995.

11. McCaffrey, T. A., D. J. Falcone, C. F. Brayton, L. A. Agarwal, F. G. P. Welt, and B. B. Weksler. 1989. Transforming growth factor beta activity is potentiated by heparin via dissociation of the transforming growth factor-beta/ alpha2-macroglobulin inactive complex. J. Cell Biol. 109:441-448.

12. Lindner, V., N. E. Olson, A. W. Clowes, and M. A. Reidy. 1992. Inhibition of smooth muscle cell proliferation in injured rat arteries. Interaction of heparin with basic fibroblast growth factor. J. Clin. Invest. 90:2044-2049.

13. Majack, R. A., S. C. Cook, and P. Bornstein. 1985. Platelet-derived growth factor and heparin-like glycosaminoglycans regulate thrombospondin synthesis and deposition in the matrix by smooth muscle cells. J. Cell Biol. 101:10591070.

14. Majack, R. A., S. C. Cook, and P. Bornstein. 1986. Regulation of smooth muscle cell growth by components of the extracellular matrix: an autocrine role for thrombospondin. Proc. Natl. Acad. Sci. USA. 83:9050-9054.

15. Au, Y. P. T., R. D. Kenagy, and A. W. Clowes. 1992. Heparin selectively inhibits the transcription of tissue-type plasminogen activator in primate arterial smooth muscle cells during mitogenesis. J. Biol. Chem. 267:3438-3444.

16. Au, Y. P. T., K. F. Montgomery, and A. W. Clowes. 1992. Heparin inhibits collagenase gene expression mediated by phorbol ester-responsive element in primate arterial smooth muscle cells. Circ. Res. 70:1062-1069.

17. Clowes, A. W., M. M. Clowes, T. R. Kirkman, C. L. Jackson, Y. P. T. Au, and R. Kenagy. 1992. Heparin inhibits the expression of tissue-type plasminogen activator by smooth muscle cells in injured rat carotid artery. Circ. Res. 70:11281136.

18. Wilhelm, S. M., I. Collier, B. L. Marmer, A. Z. Eisen, G. A. Grant, and G. I. Goldberg. 1989. SV-40-transformed human lung fibroblasts secrete a 92kDa type IV collagenase which is identical to that secreted by normal human macrophages. J. Biol. Chem. 264:17213-17221.

19. Wilhelm, S. M., I. E. Collier, A. Kronberger, A. Z. Eisen, B. L. Marmer, G. A. Grant, E. A. Bauer, and G. I. Goldberg. 1987. Human skin fibroblast 
stromelysin: structure, glycosylation, substrate specificity, and differential expression in normal and tumorigenic cells. Proc. Natl. Acad. Sci. USA. 84:6725-6729.

20. Stricklin, G. P., E. A. Bauer, J. J. Jeffrey, and A. Z. Eisen. 1977. Human skin collagenase: isolation of precursor and active forms from both fibroblast and organ cultures. Biochemistry. 16:1607-1615.

21. Welgus, H. G., and G. P. Stricklin. 1983. Human skin fibroblast collagenase inhibitor: Comparative studies in human connective tissues, serum, and amniotic fluid. J. Biol. Chem. 258:12259-12264.

22. Ross, R., and B. Kariya. 1980. Morphogenesis of vascular smooth muscle in atherosclerosis and cell culture. In Handbook of Physiology-The Cardiovascular System II. D. Bohr, editor. American Physiological Society, Bethesda, MD. 69-91.

23. Libby, P., and K. V. Obrien. 1984. Culture of quiescent arterial smooth muscle cells in a defined serum-free medium. J. Cell. Physiol. 115:217-223.

24. Laemmli, U. K. 1970. Cleavage of structural proteins during the assembly of the head of bacteriophage T4. Nature (Lond.). 227:680-685.

25. Zehr, B. D., T. J. Savin, and R. E. Hall. 1989. A one-step, low background Coomassie staining procedure for polyacrylamide gels. Anal. Biochem. 182:157159.

26. Chomczynski, P., and N. Sacchi. 1987. Single-step method of RNA isolation by acid guanidinium thiocyanate-phenol-chloroform extraction. Anal. Biochem. 162:156-159.

27. Angel, P., I. Baumann, B. Stein, H. Delius, H. J. Rahmsdorf, and P. Herrlich. 1987. 12-0-Tetradecanoyl-Phorbol-13-Acetate induction of the human collagenase gene is mediated by an inducible enhancer element located in the 5'-flanking region. Mol. Cell. Biol. 7:2256-2266.

28. Stahle-Backdahl, M., B. D. Sudbeck, A. Z. Eisen, H. B. Welgus, and W. C. Parks. 1992. Expression of 92-kDa Type IV collagenase mRNA by Eosinophils Associated with Basal Cell Carcinoma. J. Invest. Dermatol. 99:497-503.

29. Muller, D., B. Quantin, M.-C. Gesnel, R. Millon-Collard, J. Abecassis, and R. Breathnach. 1988. The collagenase gene family in humans consists of at least four members. Biochem. J. 253:187-192.

30. Huhtala, P., R. L. Eddy, Y. S. Fan, M. G. Byers, T. B. Shows, and K. Tryggvason. 1990. Completion of the primary structure of the human type IV collagenase preproenzyme and assignment of the gene (CLG4) to the q21 region of chromosome 16. Genomics. 6:554-559.

31. Forough, R., S. Nikkari, D. Hasenstab, T. Au, and A. Clowes. 1993. cDNA Cloning and Sequencing of Baboon Tissue Inhibitor of Metalloproteinase1 (TIMP-1). FASEB (Fed. Am. Soc. Exp. Biol.) J. 7:537a. (Abstr.)

32. Tso, J. Y., X.-H. Sun, T. Kao, K. S. Reece, and R. Wu. 1985. Isolation and characterization of rat and human glyceraldehyde-3-phosphate dehydrogenase cDNAs: genomic complexity and molecular evolution of the gene. Nucleic Acids Res. 13:2485-2502.

33. Cooper, T. W., E. a. Bauer, and A. Z. Eisen. 1982. Enzyme-linked immunosorbent assay for human skin collagenase. Collagen Rel. Res. 3:205-216.

34. Overall, C. M., J. L. Wrana, and J. Sodek. 1989. Independent regulation of collagenase, $72-\mathrm{kDa}$ progelatinase, and metalloproteinase inhibitor expression in human fibroblasts by transforming growth factor- $\beta$. J. Biol. Chem. 264:18601869.

35. Hipps, D. S., R. M. Hembry, A. J. P. Docherty, J. J. Reynolds, and G. Murphy. 1991. Purification and characterisation of human 72-kDa gelatinase (type IV collagenase). Use of immunolocalisation to demonstrate the non-coordinate regulation of the $72-\mathrm{kDa}$ and $95-\mathrm{kDa}$ gelatinases by human fibroblasts. Biol. Chem. Hoppe-Seyler 372:287-296.

36. Brown, P. D., A. T. Levy, I. M. K. Margulies, L. A. Liotta, and W. G. Stetler-Stevenson. 1990. Independent expression and cellular processing of $M$ 72,000 type IV collagenase and interstitial collagenase in human tumorigenic cell lines. Cancer Res. 50:6184-6191.

37. Henney, A. M., P. R. Wakeley, M. J. Davies, K. Foster, R. Hembry, G. Murphy, and S. Humphries. 1991. Localization of stromelysin gene expression in atherosclerotic plaques by in situ hybridization. Proc. Natl. Acad. Sci. USA $88: 8154-8158$

38. Southgate, K. M., M. Davies, R. F. G. Booth, and A. C. Newby. 1992. Involvement of extracellular-matrix-degrading metalloproteinases in rabbit aortic smooth-muscle cell proliferation. Biochem. J. 288:93-99.

39. Yanagi, H., Y. Sasaguri, K. Sugama, M. Morimatsu, and H. Nagase. 1991. Production of tissue collagenase (matrix metalloproteinase 1) by human aortic smooth muscle cells in response to platelet-derived growth factor. Atherosclerosis. 91:207-216.

40. Kishi, J.-I., and T. Hayakawa. 1989. Synthesis of latent collagenase and collagenase inhibitor by bovine aortic medial explants and cultured medial smooth muscle cells. Connect. Tissue Res. 19:63-76.

41. Pelletier, J.-P., M.-P. Faure, J. A. DiBattista, S. Wilhelm, D. Visco, and J. Martel-Pelletier. 1993. Coordinate synthesis of stromelysin, interleukin-1, and oncogene proteins in experimental osteoarthritis. A immunohistochemical study. Am. J. Pathol. 142:95-105.

42. Clowes, A. W., M. M. Clowes, Y. P. T. Au, M. A. Reidy, and D. Belin. 1990. Smooth muscle cells express urokinase during mitogenesis and tissue-type plasminogen activator during migration in injured rat carotid artery. Circ. Res. 67:61-67.
43. Booyse, F. M., J. Scheinbuks, J. Radek, G. Osikowicz, S. Feder, and A. J. Quarfoot. 1981. Immunological identification and comparison of plasminogen activator forms in cultured normal human endothelial cells and smooth muscle cells. Thromb. Res. 24:495-504.

44. Sperti, G., R. T. J. Van Leeuwen, P. H. A. Quax, A. Maseri, and C. Kluft 1992. Cultured rat aortic vascular smooth muscle cells digest naturally produced extracellular matrix: Involvement of plasminogen-dependent and plasminogenindependent pathways. Circ. Res. 71:385-392.

45. Nagase, H., J. J. Enghild, K. Suzuki, and G. Salveson. 1990. Stepwise activation mechanisms of the precursor of matrix metalloproteinase 3 ( stromelysin) by proteinases and (4-aminophenyl)mercuric acetate. Biochemistry. 29:5783-5789.

46. Eeckhout, Y., and G. Vaes. 1977. Further studies on the activation of procollagenase, the latent precursor of bone collagenase. Effects of lysosomal cathepsin B, plasmin and kallikrein, and spontaneous activation. Biochem. $J$. 166:21-31.

47. Murphy, G., S. Atkinson, R. Ward, J. Gavrilovic, and J. J. Reynolds. 1992. The role of plasminogen activators in the regulation of connective tissue metalloproteinases. Ann. NY Acad. Sci. 667:1-12.

48. Suzuki, K. J. J. Enghild, T. Morodomi, G. Salvesen, and H. Nagase. 1990 Mechanisms of activation of tissue procollagenase by matrix metalloproteinase 3 (stromelysin). Biochemistry. 29:10261-10270.

49. Unemori, E. N., M. J. Bair, E. A. Bauer, and E. P. Amento. 1991. Stromelysin expression regulates collagenase activation in human fibroblasts. Dissociable control of two metalloproteinases by interferon-gamma. J. Biol. Chem. 266:23477-23482.

50. Ogata, Y., J. J. Enghild, and H. Nagase. 1992. Matrix metalloproteinase 3 (stromelysin) activates the precursor for the human matrix metalloproteinase 9. J. Biol. Chem. 267:3581-3584.

51. Reith, A., and G. J. Rucklidge. 1992. Invasion of brain tissue by primary glioma: evidence for the involvement of urokinase-type plasminogen activator as an activator of type IV collagenase. Biochem. Biophys. Res. Commun. 186:348354

52. Keski-Oja, J., J. Lohi, A. Tuuttila, K. Tryggvason, and T. Vartio. 1992 Proteolytic Processing of the 72,000-Da Type IV Collagenase by Urokinase Plasminogen Activator. Exp. Cell Res. 202:471-476.

53. Desrochers, P. E., J. J. Jeffrey, and S. J. Weiss. 1991. Interstitial collagenase (matrix metalloproteinase-1) expresses serpinase activity. J. Clin. Invest. $87: 2258-2265$.

54. Okada, Y., S. Watanabe, I. Nakanishi, J. Kishi, T. Hayakawa, W. Watorek, J. Travis, and H. Nagase. 1988. Inactivation of tissue inhibitor of metalloproteinases by neutrophil elastase and other serine proteinases. FEBS (Fed. Eur Biochem. Soc.) Lett. 229:157-160.

55. Cochran, D. L., J. J. Castellot, Jr., J. M. Robinson, and M. J. Karnovsky. 1988. Heparin modulates the secretion of a major excreted protein-like molecule by vascular smooth muscle cells. Biochim. Biophys. Acta 967:289-295.

56. Kenagy, R. D., Y. P. T. Au, and A. W. Clowes. 1990. Effects of heparin on urokinase expression and mitogenesis of arterial smooth muscle cells. FASEB (Fed. Am. Soc. Exp. Biol.) J. 4:490a. (Abstr.)

57. Weiss, J. B., C. R. Hill, B. McLaughlin, and S. Elstow. 1983. Potentiating effect of heparin in the activation of procollagenase by a low-Mr angiogenesis factor. FEBS (Fed. Eur. Biochem. Soc.) Lett. 163:62-65.

58. Marsh, N. 1990. Does heparin stimulate fibrinolysis. Br. J. Haematol. 76:163-167.

59. Rifkin, D. B., R. Tsuboi, and P. Mignatti. 1989. The role of proteases in matrix breakdown during cellular invasion. Am. Rev. Respir. Dis. 140:1112 1113.

60. Kirchheimer, J. C., and H. G. Remold. 1989. Endogenous receptor-bound urokinase mediates tissue invasion of human monocytes. J. Immunol. 143:2634 2639.

61. Alexander, C. M., and Z. Werb. 1992. Targeted disruption of the tissue inhibitor of metalloproteinases gene increases the invasive behavior of primitive mesenchymal cells derived from embryonic stem cells in vitro. J. Cell Biol. 118:727-739.

62. Mignatti, P., R. Tsuboi, E. Robbins, and D. B. Rifkin. 1989. In vitro angiogenesis on the human amniotic membrane: requirement for basic fibroblast growth factor-induced proteinases. J. Cell Biol. 108:671-682.

63. Goodman, L. V., and S. R. Ledbetter. 1992. Secretion of stromelysin by cultured dermal papilla cells: differential regulation by growth factors and functional role in mitogen-induced cell proliferation. J. Cell. Physiol. 151:41-49.

64. Kenagy, R. D., C. Hart, and A. W. Clowes. 1993. Role for growth factors and proteinases in the migration of smooth muscle cells through native extracellular matrix in vitro. FASEB (Fed. Am. Soc. Exp. Biol.) J. 7:637a. (Abstr.)

65. McMurray, H. F., D. P. Parrott, and D. E. Bowyer. 1991. A standardised method of culturing aortic explants, suitable for the study of factors affecting the phenotypic modulation, migration and proliferation of aortic smooth muscle cells. Atherosclerosis. 86:227-237.

66. Castellot, J. J., Jr., L. A. Pukac, B. L. Caleb, T. C. Wright, Jr., and M. J. Karnovsky. 1989. Heparin selectively inhibits a protein kinase C-dependent 
mechanism of cell cycle progression in calf aortic smooth muscle cells. J. Cell Biol. 109:3147-3155.

67. Wright, T. C., Jr., L. A. Pukac, J. J. Castellot, Jr., M. J. Karnovsky, R. A Levine, H. Y. Kim-Park, and J. Campisi. 1989. Heparin suppresses the induction of c-fos and c-myc mRNA in murine fibroblasts by selective inhibition of a protein kinase C-dependent pathway. Proc. Natl. Acad. Sci. USA. 86:3199-3203.

68. Pukac, L. A., M. E. Ottlinger, and M. J. Karnovsky. 1992. Heparin suppresses specific second messenger pathways for protooncogene expression in rat vascular smooth muscle cells. J. Biol. Chem. 267:3707-3711.

69. Herbert, J-M., and J-P. Maffrand. 1991. Effect of pentosan polysulphate, standard heparin and related compounds on proteinkinase $\mathrm{C}$ activity. Biochim. Biophys. Acta. 1091:432-441.

70. Angel, P., and M. Karin. 1991. The role of Jun, Fos and the AP-1 complex in cell-proliferation and transformation. Biochim. Biophys. Acta. 1072:129-157.

71. Frisch, S. M., and H. E. Ruley. 1987. Transcription from the stromelysin promoter is induced by interleukin-1 and repressed by dexamethasone. J. Biol. Chem. 262:16300-16304.

72. Huhtala, P., A. Tuuttila, L. T. Chow, J. Lohi, J. Keski-Oja, and K. Tryggvason. 1991. Complete structure of the human gene for 92-kDa Type IV collagenase Divergent regulation of expression for the 92- and 72-kilodalton enzyme genes in HT-1080 cells. J. Biol. Chem. 266:16485-16490.

73. Medcalf, R. L., M. Ruegg, and W-D. Schleuning. 1990. A DNA motif related to the cAMP-responsive element and an exonlocated activator protein-2 binding site in the human tissue-type plasminogen activator gene promoter cooperate in basal expression and convey activation by phorbol ester and cAMP. $J$. Biol. Chem. 265:14618-14626.

74. Huhtala, P., L. T. Chow, and K. Tryggvason. 1990. Structure of the human type IV collagenase gene. J. Biol. Chem. 265:11077-11082.

75. Gutman, A., and B. Wasylyk. 1990. The collagenase gene promoter contains a TPA and oncogene-responsive unit encompassing the PEA3 and AP-1 binding sites. EMBO (Eur. Mol. Biol. Organ.) J. 9:2241-2246.
76. Auble, D. T., and C. E. Brinckerhoff. 1991. The AP-1 sequence is necessary but not sufficient for phorbol induction of collagenase in fibroblasts. Biochemistry. 30:4629-4635.

77. Campbell, C. E., A. M. Flenniken, D. Skup, and B. R. G. Williams. 1991. Identification of a serum- and phorbol ester-responsive element in the murine tissue inhibitor of metalloproteinase gene. J. Biol. Chem. 266:7199-7206.

78. Kerr, L. D., D. B. Miller, and L. M. Matrisian. 1990. TGF- $\beta 1$ inhibition of Transin/Stromelysin Gene Expression is mediated through a Fos binding Sequence. Cell. 61:267-278.

79. Degen, S. J. F., B. Rajput, and E. Reich. 1986. The human tissue plasminogen activator gene. J. Biol. Chem. 261:6972-6985.

80. Tryggvason, K., P. Huhtala, A. Tuuttila, L. Chow, J. Keski-Oja, and J. Lohi. 1990. Structure and expression of type IV collagenase genes. Cell Differ. Dev. 32:307-312.

81. Sato, Y., and D. B. Rifkin. 1989. Inhibition of endothelial cell movement by pericytes and smooth muscle cells: activation of a latent transforming growth factor-like molecule by plasmin during co-culture. J. Cell Biol. 109:309-315.

82. Au, Y. P. T., D. R. Morris, and A. W. Clowes. 1993. Heparin inhibits the transcription of tissue-type plasminogen activator and interstitial collagenase in part by suppressing the expression of jun-B in baboon vascular smooth muscle cells. FASEB (Fed. Am. Soc. Exp. Biol.) J. 7:316a. (Abstr.)

83. Castellot, Jr., J. J., K. Wong, B. Herman, R. L. Hoover, D. F. Albertini, T. C. Wright, B. L. Caleb, and M. J. Karnovsky. 1985. Binding and internalization of heparin by vascular smooth muscle cells. J. Cell. Physiol. 124:13-20.

84. Fritze, L. M. S., C. F. Reilly, and R. D. Rosenberg. 1985. An antiproliferative heparan sulfate species produced by postconfluent smooth muscle cells. $J$. Cell Biol. 100:1041-1049.

85. Castellot, J. J., Jr., M. L. Addonizio, R. Rosenberg, and M. J. Karnovsky 1981. Cultured endothelial cells produce a heparin-like inhibitor of smooth muscle cell growth. J. Cell Biol. 90:372-379.

86. Ishihara, M., and H. E. Conrad. 1989. Correlations between heparan sulfate metabolism and hepatoma growth. J. Cell. Physiol. 138:467-476. 